clay, that is of the mud, \&c., which then issued in streams from beneath the glaciers, and contains the pebbles derived from distant loctlities which had drifted in iceberg; and coast-ice, and been dropped into it, the land being raised to a considerable extent when, upon the return of a more genial climate, it was relieved of its load of ice and snow.

Prof. N. S. Shaler, of Harvard College, U.S.A., in 1874 (Mem. Boston Soc. Nat. Hist. vol. ii.), considering that by the hypothesis of Adhemar the conditions which would have resulted were not fulfilled during the last Glacial period, concluded that we may more reasonably look to the weight of ice then accumulated on the continents for the depression of the land areas it occupied.

In a paper on the "Cause of the Glacial Period," read before Section $\mathrm{C}$ at the meeting of the British Association at Bristol, I875 (Report, p. 79; also Geol. Mag., Decade II., vol. ii.) I a tduced evidence tending to prove that such a subsidence of the Isthmus of Panama has taken place as would allow a diversion of the equatorial waters of the Atlantic into the Pacific; as a consequence of which similar effects to those which occurred during the Glacial period might have been produced. The formation of the Canal ought to afford to competent observers absolute proof whether such has been the case or not. In the course of the essay I ascribed not only the subsidence during the Glacial period, but also that now rapidly progressing in Greenland, to the weight of the greatly increased accumulation of snow ; and that the rise of the land in Norway is dependent on the removal of pressure by the melting or diminution of the glaciers. It does not appear unlikely that to a great extent the rising of the Andes may be due to the dissolution of the snow which once covered the me mountains in a greatly increased degree, it may have been coatemporaneonsly with the Glacial periol in Europe and North America; and in part to the transfer of pressure, by the materials derived from its flanks and brought down by the Amazon and its tributaries forming at its delta the "measures" in this great cral-field of South America $n \mathrm{w}$ in process of formation.

Mr. J. Starkie Gardner, at a much later period (Geol. Mag., June, I88I) stated that great accumulations of ice in the Glacial period seem to have been accompanied by subsidence, and even Greenland at the present day may be sinking under its ice-cap. In the same year the Rev. O. Fisher, in "Physics of the Earth"s Crust" (p. 223), accomnted for the raised shell beds found in Scandinavia at an altitude of 700 feet, by the country having been formerly depressed owing to its being loaded with heavy ice field; and that its gradual subsequent rise may have been calsed by the ice having melted off. He remarks that similar movements have occurred and are now going on in Greenland and that the subsidence of 6 or 8 feet in a century may possibly be accounted for by the snow-fall being at present greater than is carried off by the glaciers and evaporation.

D aring the present year Mr. W. F. Stanley (NATuRE, vol, xxvii. p. 523) held that the cause of the coast of Greenland sinking is the weight of the present accumulation of ice upon that continent. Quite recently Mr. Searles V. Woud (Geol. Mag., July, I883, footnote) thinks that the overwhelming of reindeer pastares by the ice during the centuries of Danish occupation, and the indications of subsidence afforded by the position of ancient dwelling;, may show that the ice is now augmenting, and the land sinking under its weight.

But the great question is not to whom belongs the priority of attributing the depression of the land during the Glacial period, and at present in Greenland, to the weight of accimulated snow, and the reelevation to its renoval; even this explanation of the phenomesa under consideration, important though it may be, is but an item in the still greater oae, namely, whether the depres. sion which has taken place and is still in progress at the mouths of great rivers, in their deltas, in the estuaries and bays into which, emptying themselves, they carry mud, sand, pebbles, and other debris, is caused by the weight of these accumulated deposits pressing down the crust of the earth beneath them, thus permitting further accumulation to any extent; and also whether the subsidence, which by every one is conceded to have occurred during the deposition of all stratified rocks, from the earliest of which we can read the record in the "great stone book" to those now in progress, is due to the same cause--the weight of the materials of which they have been formed.

The converse has also to be inquired into, whether the eleva. tion of the land and the formation of hills and mountains is the result of the abrasion of the land and the transfer of the disin. te orated materials to a distance by rain and rivers; thus reliev- ing by so much the locality from which they have been removed of the weight pressing on the crust of the earth. The highest hills in a district are those from which the greatest amount has been removed by denudation, their summits not unfrequently consisting of the lowest rocks in the geological series of the neighbourhood.

Birkenhead, September 22

Charles Ricketts

I QUITE agree with Mr. Mackie in believing that " the connection between sedimentation and subidence on the one hand, and between denudation and elevation on the other," are "simply concomitant effects of the same cause;" that, in fact, depressions in the earth's crust are the cause of sedimentary deposits, and not the deposits the cause of the depressions, and, further, that the elevations and depressions are caused by lateral pressure developed by the shrinking of the earth's crust ; but is it necessary that certain parts of a depressed area should be "strengthened by volcanic outbursts, \&c."? I do not think so.

If a magazine or book with a paper cover be held close, and pressed from back to front, the mass of the leaves is thrown into anticlinal and synclinal curves though the book is at no point stronger than at any other; the pressure is broaght to bear upon the book, and as it cannot "telescope," it is necessarily bent upwards and downwards. Is this not something like what happens to the rock?

Take, for example, the Old Red Sandstone between the base of the Grampians and the Carboniferous rocks of Fife. This is a plain partly composed of sandstones, partly of sandstone with interbedded volcanic rocks, and partly of solid masses of volcanic ejecta. The plain has been bent into two anticliral and two synclinal curves.

In such a varied area, if anywhere, one would expect to find evidence of the inflaence of the relative strength of the rocks in $m$ sdifying their curvature.

The syncline nearest to the Grampians is mainly composed of sandstone and conglomerates; as these rocks bend up towards the anticlinal axis to the south, the Sidlaw Hills (composed of hard sandstones and interbedded porphyrite, \&c.) present a very striking example of strengthening of the beds; still they are neither on the anticlinal nor the synclinal axis, for though near to and towering high above the former, they lie on the slope of the beds dipping towards the north. The rocks of the second syncline are sandstones with intrusive and interbedded lavas, the volcanic rocks greatly increasing in proportion to the sedimentary towards the synclinal axis near the estuary of the Tay, towards which the rocks are gently bent up, while across the estuary, which occupies the position of the denuded arch of the anticline, the rocks are almost entirely sheets of lava, with volcanic breccias, \&c.

Thus we have a synclinal and anticlinal curve, both of sandstone, while the hard and thickly-bedded volcanic rocks form part of the slope between them, and again we have a syncline partly composed of interbedded lavas and sandstones, while the almost entirely volcanic rocks are bent up into an anticline.

It would therefore seem that the quality and thickness of the rock masses have very little influence upon the form of the curves into which they are bent.

Newport, Fife

\section{Photography and Still Life}

I HAVE been assured, by a gentleman to whose opinion all dabblers in science photography must bow, that the following method of photographing objects of still life was unknown to him, and that its publication might prove useful to others.

Having some years ago to photograph a series of implements to illu itrate a paper on the Borness Cave, I was met at the outset by the difficulty of avoiding cast shadows and such accessories as were needful for posing the objects to be copied. It occurred to me that a pane of glass, a white cloth, and some beeswax would meet the difficulty; as objects fixed to the glass by beeswax with a white cloth behind them would "come out" on a white ground free from the shadows and accessories I wished to avoid. Having been recently asked to photograph some important bones, teeth, and flint implements, necessity, "the mother of invention," has much improved on the original rough process, and I can confidently recoinmend the following cheap apparatus as extremely efficient, viz., a square pane of plate glass with a hole drilled in the centre (for fastening such 